\title{
Techno-Economic Analysis of Retrofitted Electric Coaster Introduction in University Campus
}

\author{
Ataur Rahman ${ }^{1 *}$, Sany Izan Ihsan ${ }^{1}$ and Ahmed Faris Ismail ${ }^{1}$ \\ DOI: $10.9734 /$ bpi/naer/v13/6968D
}

\begin{abstract}
Green transportation concentrates around resource efficiency and effectiveness, resulting in a lower carbon and healthier environment for the nation through lowering greenhouse gas emissions. Promising novel technologies may be the ultimate solution, but innovation will only happen if society plays a key role in the development of electric vehicles aimed at reducing carbon emissions. Understanding how markets work to save fuel is necessary for developing successful and affordable policies to enable the implementation of low-carbon technologies in accordance with political goals. The goal of this research is to construct an all-electric mini-coaster (14 seats) by retrofitting a diesel engine Mercedes Benz Van with a $15 \mathrm{kWh}$ lithium-iron-phosphate battery (LiFePO4). The coaster is propelled by an AC induction motor with a peak power of $60 \mathrm{~kW}$ and torque of $150 \mathrm{Nm}$. A $3.44 \mathrm{kWh}$ lithium battery has also been employed as an auxiliary battery to run the battery cooling system and passenger compartment cooling system. With a single fully charged battery, the coaster can ride 40 kilometers. The coaster's power consumption is $340 \mathrm{Wh} / \mathrm{km}$ [cost USD 0.025 (RM0.12) per km] depending on Malaysian gasoline prices. The coaster's real operating cost is RM144 per month when powered by a battery, and RM600 per month when powered by an internal combustion engine. As a result, the cost-effective electric mini-coater benefits both the International Islamic University of Malaysia (IIUM) and the environment.
\end{abstract}

Keywords: Electric coaster; cost-benefit analysis; energy saving; emission reduction; environmentally sustainable.

\section{INTRODUCTION}

In a global context, it is critical to promote sustainable energy policies that encourage economic growth while also protecting the environment, notably in terms of reducing greenhouse-gas emissions that contribute to climate change. Also, to support global energy technology collaboration in order to secure future energy supplies and mitigate their environmental impact, including through improved energy efficiency and the development and deployment of low-carbon technologies, and to find solutions to global energy challenges through engagement and dialogue with non-member countries, industry, and academia. In wake of Rio+20 and the commitment of $\$ 175$ billion from the eight largest multi-lateral banks, sustainable transportation initiatives will continue to gain momentum. EVs will be one part of larger, sustainable transport solutions. Continuing reductions in battery prices could bring the total cost of ownership of electric transport below that for conventional-fuel vehicles by 2025 , even with low oil prices. The electric vehicles will hit 41 million by 2040 , representing $35 \%$ of new light duty vehicle sales. This would be almost 90 times the equivalent figure for 2015, when EV sales are estimated to have been 462,000 , some $60 \%$ up on 2014 . The research estimates that the growth of EVs will displace 13 million barrels per day of crude oil but use 2700TWh of electricity. This would be equivalent to $11 \%$ of global electricity demand in 2011. It assumes that a BEV with a $60 \mathrm{kWh}$ battery will travel $322 \mathrm{~km}$ (200 miles) by full charging battery [1]. Lithium-ion battery costs have already dropped by $65 \%$ since 2010 , reaching $\$ 350$ per kWh last year and it would be below $\$ 120$ per kWh by

${ }^{1}$ Department of Mechanical Engineering, Kulliyyah of Engineering, International Islamic University Malaysia, $50728 \mathrm{KL}$, Malaysia.

${ }^{*}$ Corresponding author: E-mail: arat@iium.edu.my; 
2030 [2]. Battery prices fell 35\% last year and are on a trajectory to make unsubsidised electric vehicles as affordable as their gasoline counterparts in the next six years, according to a new analysis of the electric-vehicle market by Bloomberg new energy finance (BNEF). That will be the start of a real mass-market lift off for electric cars. The lithium-ion battery technology has attracted more attention, especially for an electric vehicle, due to a clean alternative, domestic energy independence, cost and savings, low self-discharge rate $(6-10 \%)$, high terminal voltage, high discharge current, non-memory effect and longer life cycle [3-4].

Table 1. Emission for a kWh power generation [5]

\begin{tabular}{lllll}
\hline Fuel & \multicolumn{4}{c}{ Emission (Kg/kWh) } \\
\cline { 2 - 5 } & $\mathbf{C O}_{\mathbf{2}}$ & $\mathbf{S O}_{\mathbf{2}}$ & $\mathbf{N O} \mathbf{x}_{\mathbf{x}}$ & $\mathbf{C O}$ \\
\hline Coal & 1.18 & 0.014 & 0.01 & 0.0002 \\
Petroleum & 0.85 & 0.017 & 0.003 & 0.0002 \\
Gas & 0.53 & 0.001 & 0.001 & 0.001 \\
Hydro & 0.00 & 0.00 & 0.00 & 0.00 \\
\hline
\end{tabular}

Unlike carbon fuel storage, electric grid storage has virtually no reaLtime storage of energy. With coal fired power plants (Table 1), each kWh generated, $1.18 \mathrm{~kg} \mathrm{CO} 2$ is emitted Divided by $1.8 \mathrm{kms} / \mathrm{kWh}$ "fuel" economy of a Public Service Bus means that an EV will effectively emit $0.65 \mathrm{~kg}$ of CO per kms driven. Carbon Fuel [Diesel] bus emits $9.07 \mathrm{~kg} \mathrm{CO} 2$ per litre [5-6].

The emissions emitted by tailpipes and power plants contain more than just carbon dioxide. There's also ozone, particulate matter andcarbon monoxide. These emissions are identified as criteria air pollutants (CAP) which cause asthma, respiratory disease, heart disease in individuals. Minimising people's exposure to these emissions improves health as well as confining CAP emissions to power plants, most of which are located farther away from where people live. When analysing differences in of Electric Public Transport Vehicles and fossil fuel powered Vehicles, both operational costs and initial investment comparison undoubtedly has higher initial capital outlay involved when electric energy is being added/used. However, operational costs, including energy costs, show opposite picture, especially with large annual distances covered - electrical energy is substantially cheaper. Initial investments of changing public transportation fleet to electric buses and the costs of battery replacement still outweighs the monetary advantages gained from lower operational costs and additional environmental benefits with rapid returns on investment (ROI) [7].

\section{METHODOLOGY}

This study has been conducted for the evaluation of the impact of "Flagship Project-Low Carbon Campus" using the Retrofitting Electric Coaster development and fabrication and societal cost analysis. The benefits are quantified in this study to present a more comprehensive picture of true costs and benefits of a "Retrofitted Electric Coaster". The cost-benefit analysis of the retroffiting electric coaster has been made with including the fuel savings, maintenance costs saving, environmental impacts from reduced $\mathrm{CO}_{2}$ and carbon trading (USD50/tonne). The benefits of this project also analysis with considering the RM5 (USD1.19)/month for students' willingless to pay for the "LOW Carbon" campus campaign and program.

The assumption used in the valuation of the : (i) vehicle life time is considered 8 years (battery for electric coaster comes with a 8 years warrenty) and annual mileage is $18,000 \mathrm{~km}$, (ii) retrofitted coaster weight is $35 \%$ less than the internal combustion engine powered coaster ( total weight of the battery and battery cooling system is $200 \mathrm{~kg}$ and motor and controller weight $80 \mathrm{~kg}$, wiring and others mounting system weight is $30 \mathrm{~kg}$ while the engine weight is $325 \mathrm{~kg}$ and fuel tank weight is $100 \mathrm{~kg}$ ) (ii) Gasolene (diesel) price RM2.50 (USD0.6) per litre, (iii) electricity price RM0.21 (USD0.05) per kWh which is the average price of electricity for Malaysia residential customer until November 2019 (it is assumed that the electricity price will be remain stable over the life of the coaster, (iv) one DC-DC charging point, (v) coaster is driven in the same environment. 
The benefit analysis of the electric-coaster introduction in the campus has been made based on upfront value of the diesel engine powered coaster and retrofitted electric-coaster. The values in this analysis are mostly varied based on the diesel prices, electricity prices, maintenance cost, and other variables. Benefits also measured based on the students' willingless to pay, health benefits. All of the benefits analysis has been made based over the 8 years life of the vehicle. Electricity price is likely stable all over the 8 years while the fuel cost has been considered $10 \%$ increased annually based on the price fluction of last five years.

\subsection{Electric Coaster Development}

Basic concept of the electric transport development is to identify the power requirement of transport based on the vehicle dynamic analysis. The vehicle dynamic analysis is normally made based on three different operating modes: just-start from rest, traction and cruising. The basic mathematical model has been presented in equation (1) and (2) are used to estiamted the energy required for the transport for certain periods. The mathematical model to estimate the energy required to propel the electric vehicle can be presented as,

$$
E(t)=\frac{\left(v^{*} t\right)}{1000}\left|\begin{array}{llll}
(m g) & 0 & v & 10 \\
(m g)\left(f_{r}+G\right) & 10 & v & 40 \\
0.5 & { }_{a} C_{d} A_{f} v^{2}+f_{r} m g & 90<v & 110
\end{array}\right|
$$

where, $\mathrm{m}$ is the vehicle mass, $\mathrm{kg}, \mu$ is the road friction coefficient, $\mathrm{f}_{\mathrm{r}}$ rolling motion resistance coefficient, $\sin \theta \cong G, G$ is the grade, $\rho$ is the air density, $\mathrm{kg} / \mathrm{m}^{3}, C_{d}$ drag coefficient, $A_{f}$ frontal area, $\mathrm{m}^{2} v$ vehicle speed, $\mathrm{m} / \mathrm{s}$, and $\mathrm{t}$ time, $\mathrm{h}$. For the simulation, $\mathrm{m}$ is considered as $1000 \mathrm{~kg}, \mu$ is 0.4 , fr is 0.012 , $\sin \theta \cong G, G$ is $10 \%$ for urban mode, $\rho$ is $1.16 \mathrm{~kg} / \mathrm{m} 3, \mathrm{Cd}$ is 0.2 , Af is $1.67 \mathrm{~m}^{2}$, and $\mathrm{t}$ is 2 hours for cruising. Table 2 shows the simulation result on the energy required for the vehicle in the different mode. The energy calculation is mostly made based on the cruising speed. If the vehicle is equipped with a power pack of $55.5 \mathrm{kWh}$, the vehicle able to meet the traction power requirement of the other mode such as starting and slope climbing. Therefore, $55.5 \mathrm{kWh}$ battery pack can be considered for the vehicle to travel $200 \mathrm{~km}$ in a single charging. However, if the battery pack is considered as 33 kWh.

The discharge current $\left(\mathrm{l}_{\mathrm{b}(\mathrm{d})}\right)$ from the battery can be estimated by incorporating the traction equation [8]:

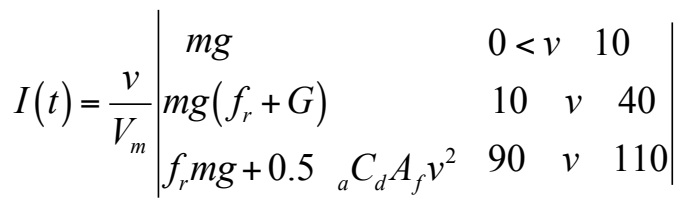

where $m$ is the mass of the vehicle in $\mathrm{kg}, g$ is the gravitational acceleration constant, $\mathrm{m} / \mathrm{s}^{2}, \mu_{r}$ the adhesion coefficient of the road, $\mathrm{P}_{\mathrm{t}(\mathrm{p})}$ is the tire pneumatic pressure of tyre in $\mathrm{kN} / \mathrm{m}^{2}, \theta$ the slope angle of the road in deg, $\rho_{a}$ is the air density in $\mathrm{kg} / \mathrm{m}^{3}, C_{D}$ is the coefficient of aerodynamic resistance, $A_{f}$ is the frontal area of the vehicle in $\mathrm{m}^{2}$ and $\mathrm{V}$ is the travelling speed of the vehicle in $\mathrm{m} / \mathrm{s}$ and $\mathrm{V}_{\mathrm{m}}$ is the motor rating voltage in volts. For the simulation: the adhesion coefficient value $\mu_{r}$ of 0.02 , highest gradient $\sin \theta=G$ equals to $3.67 \%$, air density $\rho_{a}$ equals to $1.164 \mathrm{~kg} / \mathrm{m}^{3}$ and maximum travelling speed $\mathrm{V}_{\max }$ of $120 \mathrm{~km} / \mathrm{h}$ has been considered. $\mathrm{V}_{\mathrm{m}(\mathrm{vol})}$ is the motor rating voltage in 
this study has been considered as 100 volts. The maximum power needs for the vehicle to mobile on $3.67 \%$ gradient with maximum speed of $120 \mathrm{~km} / \mathrm{h}$.

\subsection{Novel Integrated Design Methodology of E-Coaster}

The design framework for the development of the electric coaster was performed in parallel. The structural approach of parallel engineering tools, such as economic analysis (EA), finite element analysis (FEA) or design for assembly/production (DFA / DFM), was carried out to ensure that future problems in the design and manufacture of electrical supports or electrical fleet can be avoided. The proposed methodology can act as a roadmap for project planning since it defines the tools and methods that should be applied at each stage of the product design process. The methodology also serves as a checklist to avoid measurable criteria such as cost and weight.

Qualitative criteria represent the third category of design criteria that has been taken into account. Qualitative criteria were prioritized to develop a matrix of relational analysis between qualitative criteria and functional decisions in accordance with design variables. The assessment mechanism is similar to the phased approach mechanism, where all activities are analyzed and important decisions must be made after each review. Physical tests were performed to ensure that the initial objectives of the project are fully implemented. To solve the problems of the power steering, transmission functionality and life cycle, an appropriate combination of design and verification situations was carried out. Both theoretical and experimental analysis was introduced for each selected performance criterion. The manufacturing aspect of electronic coasters has been validated and optimized during road trials. The design optimization problem can be represented as generic form can be presented as,

minimize

$$
\begin{array}{rr}
G D_{i}(x), & \text { where }, i=1,2, \ldots \ldots . ., n \\
\text { subject to } E M_{j}(x)=0, & j=1,2, \ldots \ldots . ., j \\
B P_{k}(x) \leqslant 0, & k=1,2, \ldots \ldots \ldots, k
\end{array}
$$

where, $G D_{i}(x), E M_{j}(x)$ and $B P_{k}(x)$ are the function of design factor of

driveline, electric motor capacityand battery pack

$$
x=\left(x_{1}, x_{2}, \ldots \ldots ., x^{n}\right)^{T}
$$

The sustainability of the battery pack is fully depends on the battery cooling system which can be represented by the generic form of equation as,

Maximize

$$
\begin{gathered}
B P_{k}(x), \quad k=1,2, \ldots \ldots \ldots, K \\
\text { subject to BTMS }(x) \geqslant 0, \quad z=0 \%, 5 \%, 10 \%, \ldots \ldots ., 100 \%
\end{gathered}
$$

where, BTMS is the battery thermal management system. While, the battery thermal management system is crucial for the vahicle life defining.

$$
\begin{aligned}
& \text { Maximize } \\
& \qquad \operatorname{BTMS}_{z}(x) \unlhd 0 \\
& \text { subject to } C_{t}(x), \quad t=a, l, r e f ., \ldots \ldots . . ., \text { otherwise }
\end{aligned}
$$


where, $\mathrm{Ct}(\mathrm{x})$ is the channel of coolant flow design and direct expansion valve architecture which can control the flow of refrigerant (R143a) to maintain the phase of the coolant flow to the battery pack cooling ducts. The direct expansion valve has been design for the default setting for $20 \%$ liquid and $80 \%$ vapour. However, this flow has a problem at starting and over heation. The energy required of the presented retrofitted electric coaster has been estimated using the simulation model considereing the vehicle traction force requirement at any road profile is presented in Table 2 . The consideration has been made based on the vehicle propulsion: initial starting, slope, and flat road with cruising speed. Table 2 shows the vehicle needs more at the intial acceleration condition of the vehicle, which is about $16 \mathrm{kWh}$. A lithium-ion $\left(\mathrm{LiFePO}_{4}\right)$ has been design to get the terminal volatage of $150 \mathrm{~V}$, capacity of $86 \mathrm{Ah}$ and $22.5 \mathrm{kWh}$ which will provide the continuous current supply of $86 \mathrm{~A}$ for two hours.

Table 2. Energy required for an Electric Coaster

\begin{tabular}{|c|c|c|c|c|c|}
\hline \multirow[t]{2}{*}{ Traction mode } & \multirow[t]{2}{*}{$\begin{array}{l}\text { Speed } \\
(\mathrm{km} / \mathrm{h})\end{array}$} & \multirow[t]{2}{*}{$\begin{array}{l}\text { Traction } \\
\text { force }(\mathbf{k N})\end{array}$} & \multicolumn{3}{|c|}{$\begin{array}{l}150 \mathrm{~V} \text { rating motor required to propel } 29.43 \mathrm{kN} \\
\text { Electric Vehicle }\end{array}$} \\
\hline & & & Power (kW) & Current (A) & Energy (kWh) \\
\hline $\begin{array}{l}\text { Initial starting } \\
\text { (Reduction) }\end{array}$ & $0-10$ & 5.88 & 16.33 & 109 & $16.33^{*}$ \\
\hline $\begin{array}{l}\text { Traction at } 5 \% \\
\text { grad. }\end{array}$ & 20 & 2.9 & 16.11 & 107 & $16.11^{\star *}$ \\
\hline Cruising speed & 90 & 11.72 & 16.35 & 109 & $16.35^{\star \star *}$ \\
\hline
\end{tabular}

*Just start from the rest and road bump. ${ }^{* *}$ Average operation around the University Campus. ${ }^{* * *}$ Some part of the campus road

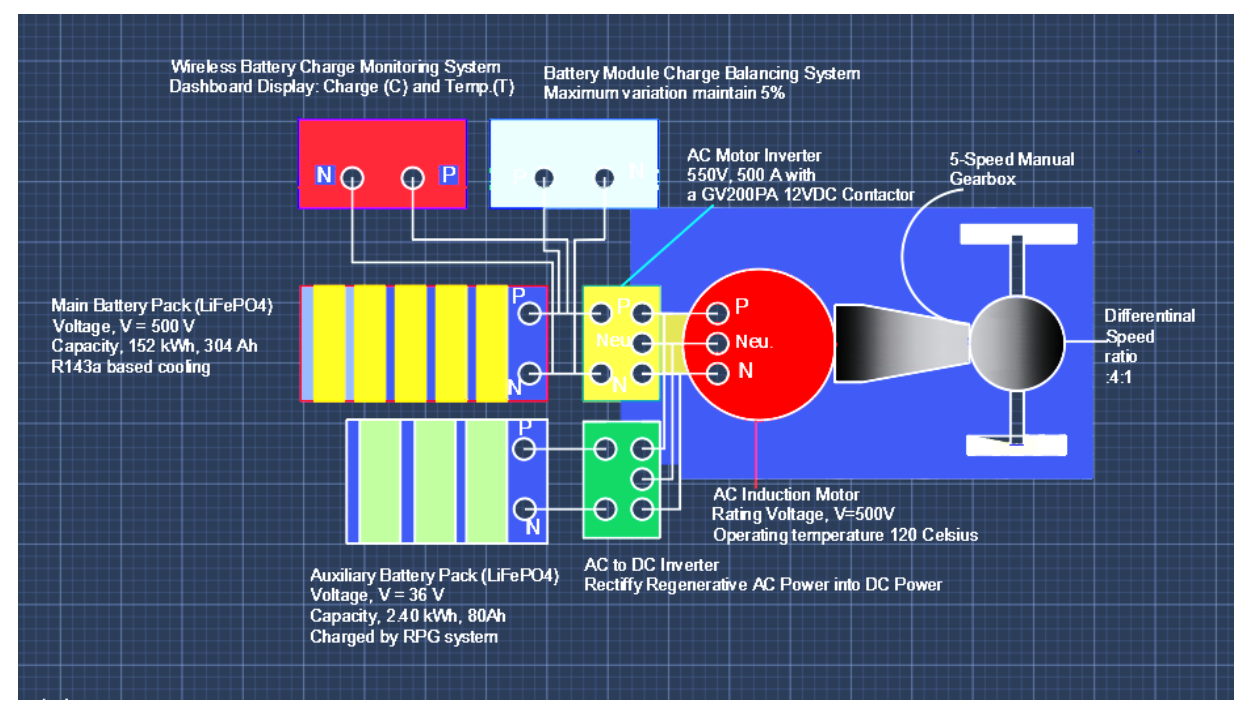

Fig. 1. Powertrain of retrofitted electric coaster

\subsection{Powertrain of Retrofitted Electric Coaster}

The integrated smart propulsion system has been innovated with integrating the refrigerant (R143a) based Lithium-ion battery thermal management system, power regenerative driveline, wireless battery monitoring system and advanced battery cell balancing system for the EC. The integrated system is able to operate the EC without any power interruption by keeping the battery temperature in the range of $30-35^{\circ} \mathrm{C}$. The power regenerative system is able to generate the electric power about $1400 \mathrm{~W}$ for each deceleration of the EC from $50 \mathrm{~km} / \mathrm{h}$ to $15 \mathrm{~km} / \mathrm{h}$, which is used to charge the battery of the EC. The wireless battery monitoring system (WBMS) is able to monitor the battery temperature and the 
level of charge of the battery. The WBMS always keep warning the driver all the way of driving. So that the driver can take action for the battery cooling and charging of the EC if necessary. The battery cells balancing system (BCBS) equalize the battery charge with the maximum variation of 10\%. Fig. 1 shows the integrated smart propulsion system of the retrofitted EC.

Power Regenerative System: The fabricated power regenerative system (PRGS) driveline is expected to recover braking power by $15 \%$ of the vehicle braking power upon deceleration from 125 $\mathrm{km} / \mathrm{h}$ to $25 \mathrm{~km} / \mathrm{h}$ based on European Urban Driving Cycle (EUDC) which can enhance the vehicle performance about $10 \%$. The regenerative power is used to charge the auxiliary battery. The PRGS driveline has been developed based on the vehicle weight, torque density and speed. PRGS electrical drive train has numerous functionalities include good torque controllability over a wide speed operating range, high torque density, high efficiency and low cost.

R143a Batter Thermal Management System: The refrigerant R143a based Lithium-ion $\left(\mathrm{LiFePO}_{4}\right)$ battery thermal management system has been developed to cool the battery pack with maintain the temperature in the range of $20-35^{\circ} \mathrm{C}$. It has been made with developing algorithm by battery discharge current data training. Heat generated from the battery is absorbed by the evaporating refrigerant inside the cooling duct and then dissipated heat to the surrounding air at the condenser. Thus the system was able to maintain the temperature of the battery $\leq 35^{\circ} \mathrm{C}$.

Wireless battery monitoring system: The wireless battery monitoring system (WBMS) network deployed in the battery to monitor instantaneous current, voltage, state-of-charge (SOC) and state-ofdischarge (SOD) and capacity $(\mathrm{AH})$ of battery cell or module. It is made with ZigBee wireless communication system and equipped with sensors, two master controllers and four slave controllers and auto switching system. In the WBMS slave controller collects the information regarding a battery pack from the employed analogue sensors (SOC \& SOD, voltage, current and temperature and mapped into its specific ranges. After that, slave controller sends the processed information to the master controller. On basis of the receiving information, the master controller takes two decisions: communication and control signal generation. To communicate with the monitoring device, master controller activates ZigBee coordinator to send the information. It sends a control signal to the slave controller 2 to turn ON/ OFF switches for the charging and discharging operation. On the monitoring and user controlled side, Master controller (B) receives the sending information via ZigBee coordinator. Then Master controller (B) processed the information and sent signal to slave controller to display information or show a level of $\operatorname{SOC}(\mathrm{t}) \& \operatorname{SOD}(\mathrm{t})$.

Battery Charge Balancing System: The battery charge balancing system has been developed with developing algorithm based on the battery electro chemistry and charge/discharge current. The algorithm has been developed based on its self-awareness to understand the current state of charge of the cells and instanteneous state of charge of the cells. So that it is able to maintain accurately state-of-charge $(\mathrm{SoC})$ and state-of-discharge $(\mathrm{SoD})$ for the individual cells. This allows the vehicle to utilize the maximum energy available from the battery for a given drive cycle whilst maintaining pack balance within the range of optimal functionality. This system is capable of preventing overcharging and over-discharging of $\mathrm{LiFePO}_{4}$ cell and able to enhance the battery SoH.

\section{ELECTRIC COASTER FABRICATION}

The retrofitted e-coaster fabrication has been made by repalced the 2.5 Iltre of diesel engine with a $22.5 \mathrm{kWh}$ battery, $52 \mathrm{~kW}$ AC induction motor of voltage $150 \mathrm{~V}$ and a controller of maximum current controlling capacity of $86 \mathrm{~A}$, battery temperature cooling and monitoring system, battery charge monitoring system and emergency switch [Ataur et al., 2014, [9]. It's battery cooling has been made with a refrigerant based cooling system which has both surface coolong and tab cooling properties [10], [Ataur et al., 2014]. The maximum energy (kWh) requirement of the coaster has been estimated by the analysis of the coaster dynamics on maximum grade of $20 \%$ (shown in Table 2). 


\subsection{Special Features}

Electric Coaster powered by $22.5 \mathrm{kWh}$ Lithium-ion battery operations in IIUM Campus would result: (i) annual reduction of $\mathrm{CO}_{2}$ emission about 15 metric tons (ii) annual savings about RM20,520 (USD5100) by eliminating fuel . It is able to travel $45 \mathrm{~km}$ by a full charge battery with maximum speed of $110 \mathrm{~km} / \mathrm{h}$. The annual income from carbon trading RM1750 (USD446 per year) considering RM220 I tonne (USD50/tonne). The regenerative traction power system makes the electric coaster $15 \%$ energy efficient. While, the two-phase evaporative cooling system is able to keep the battery temperature in the range of $25-35^{\circ} \mathrm{C}$ span battery life about $10 \%$. The performance of electric coaster can present as the generic algorithm form,

\section{Maximize}

$$
E C_{e}(t) \quad 0, \quad e=x_{1}, x_{2}, \ldots \ldots \ldots, x_{n} ; x_{n}=|100 \%|
$$

subject to $\mathrm{EM}_{j}(x), x=T(t) \square 0$, where, $T(t)=$ Ins tan teneous torque

$$
\operatorname{BTMS}_{z}(x), 20^{\circ} \mathrm{C} \quad x=(t) \quad 40^{\circ} \mathrm{C}
$$

where, $E C_{e}(t)=$ electric coaster ins $\tan$ teneous torque

During the testing and robust operation of the coaster in the International Islamic University Malaysia campus, it is identified that the cooling system is very essential to maintain the coaster life for 8 years in line with the battery life. The R413a based cooling system has been used as the cooling of the REC's battery temperature in the range of $20-40^{\circ} \mathrm{C}$.

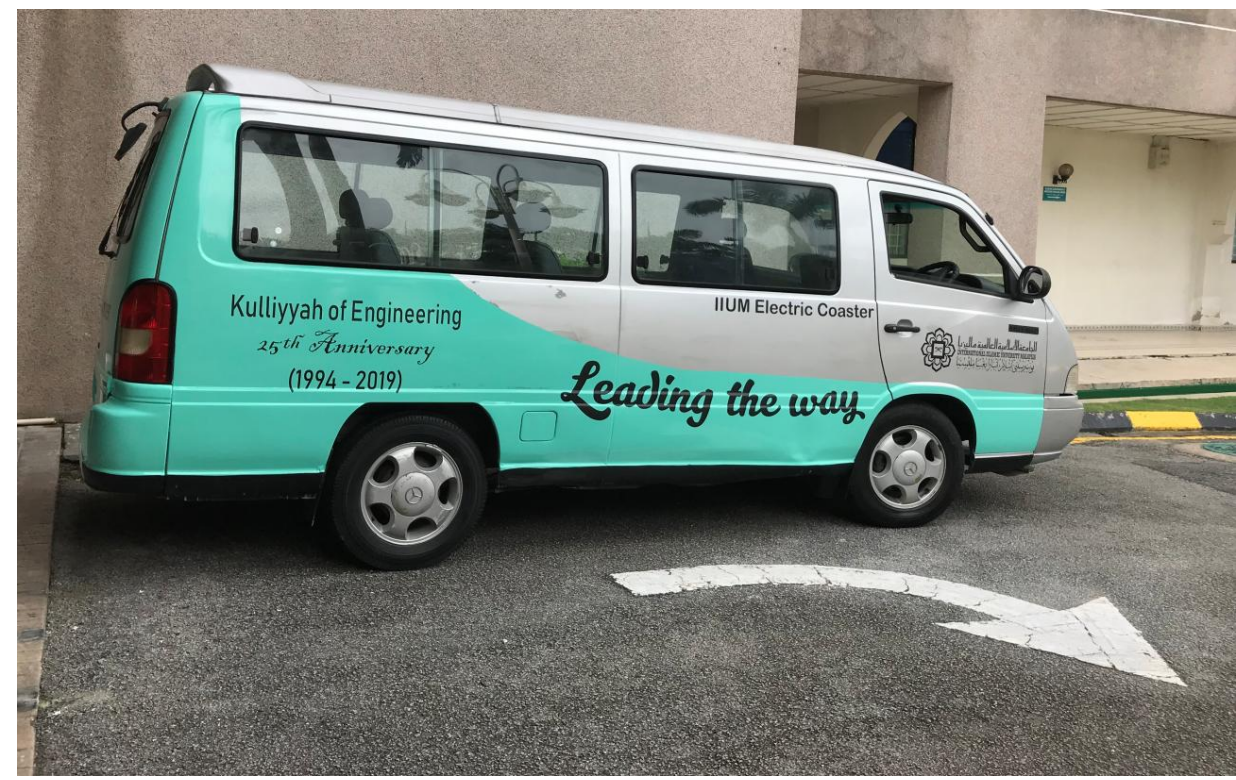

Fig. 2. Retrofitted electric coaster (REC)

\section{COST BENEFIT ANAYSIS OF ELECTRIC COASTER INTRODUCTION}

The cost benefit analysis of the REC has been made by developing the mathematical model with modification as necessary based on the development, operating and benefit of the REC introduction. The electric coaster introduction in campus justification has been made with comparing the diesel engine powered coaster operation in the campus. 


\subsection{Cost Analaysis}

The capacity to estimate costs accurately is essential if a company is to stay in business. Unfortunately, cost analysis is just an estimation process and in the best of circumstances will only provide a good approximation of the cost that will actually be engaged [11,12]. The cost targets of the product should be established in the early stages of a design process $[11,13]$. Thus, the system performance requirements are constantly re-evaluated to identify areas of potential cost reduction. The cost breakdown structure is a technique of managing cost in a major program. The cost breakdown structure should ties the activities of the product lifecycle to the available resources by subdividing the total cost into logical categories such as the functional areas and major tasks to be accomplished [14, 15]. The cost breakdown of REC has been made for the REC (shown in Fig. 2) based on the functional activities of the componets and major task for the operation. The safety of the components such as cooling system of the battery has adopted in the cost breakdown analysis.

Table 3. Cost breakdown based on the components of the REC

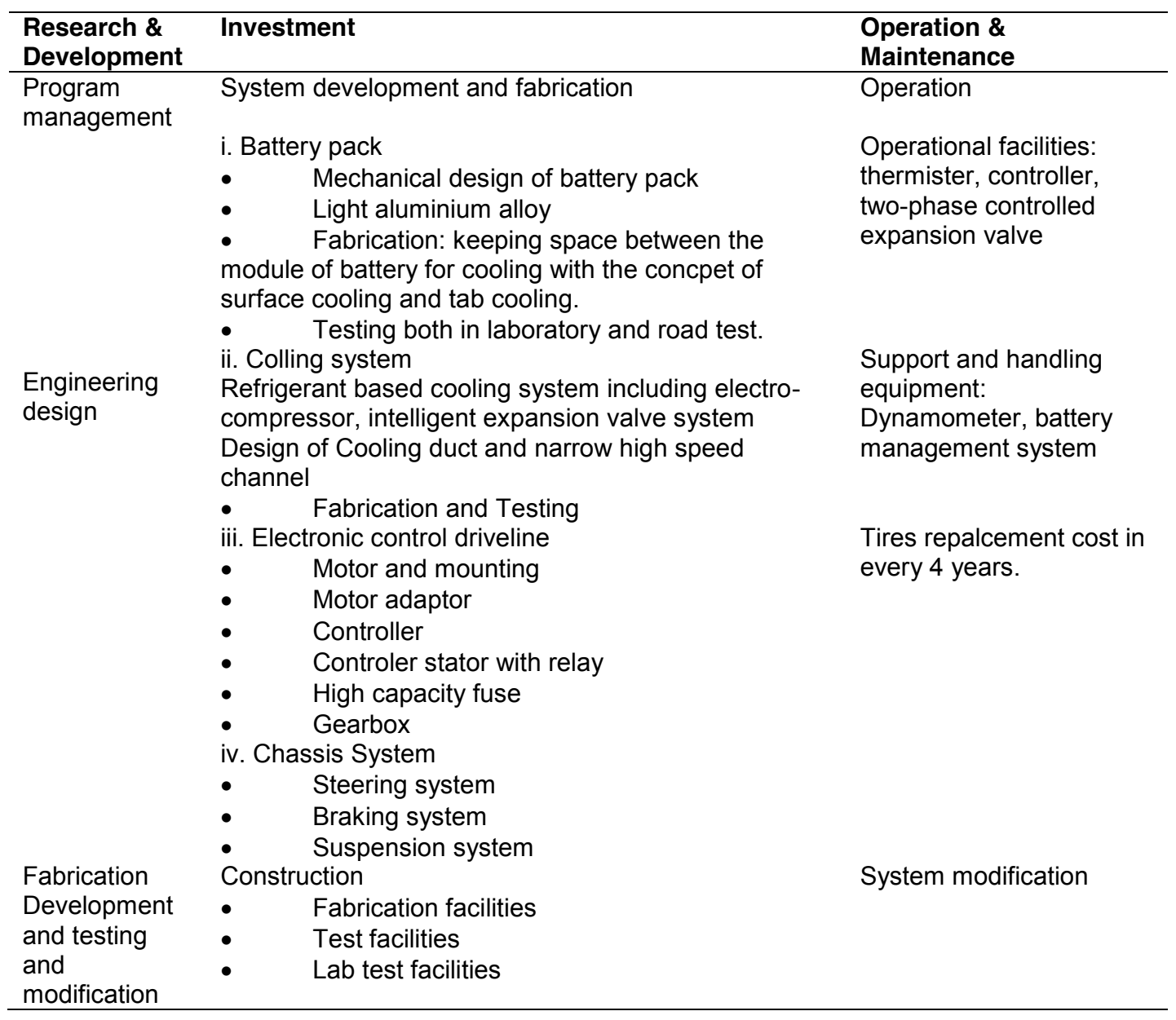

\subsection{Mathematical Model of Cost Analysis}

The annual operating cost of the electric coaster can be formulated as,

$$
\text { Cost }_{t}^{E C}=F C_{t}+\text { Energy }_{t}+{\text { Maint } \text { enance }_{t}+\text { Re }_{\text {gistration }}}_{t}
$$


where, FC is the upfront cost of the coaster. Although the e-coaster has been developed by retrofitting the engine powered coaster. The total cost of the vehicle is fixed. However, it can be splited all over the 8-years operation life of the coaster with interest rate. The splited annual cost of the coaster can be estimated as,

$$
F C(t)=\frac{P}{1 \frac{1}{1+i} \div / i} \mid
$$

where, $\mathrm{P}$ is the principal amount, $\mathrm{I}$ is the applied interest, and $\mathrm{t}$ is the life of the e-coaster based on the battery life. The Total Cost of Ownership to facilitate comparison,

$$
T C O_{t}=\sum_{0}^{T} \operatorname{Cost}_{t}
$$

Annual Net Benefit of the electric coaster operation for years can be estimated by using the equation.

$$
\begin{aligned}
& N P V_{t}=\sum_{t=1}^{N} \frac{R_{t}}{(1+r)^{t}} \\
& \text { with } R_{t}=B_{t}-C_{t}
\end{aligned}
$$

where, B is net benefit from electric coaster operation, $\mathrm{C}$ is the cost of the electric coaster including upfront, operation cost, maintenance cost, and insurance cost, $r$ is the discounted rate, $t$ is the time, $N$ is the number of years.

If the cash flow $R(t)$ is constant, the NPV is a finite geometric progression and can be modelled as,

$$
N P V(r, N, R)=R\left|\frac{1-\left|\frac{1}{1+r}\right|^{N+1}}{1-\frac{1}{1+r} \div}\right|, r \neq 0
$$

However, if the cash flow $R$ is in the variation mode over the time, the NPV(t) can be estimated as,

$$
\begin{aligned}
& \operatorname{NPV}(t)=\int_{t=0} \frac{R(t)}{(1+r)^{t}} d t \\
& \text { with } r(t)=0, \text { when the investment is over }
\end{aligned}
$$

The net present value of the EC has been presented in the Table 4, which is estimated based on 8years after with $3 \%$ interest rate.

Table 4. Estimatd cost based on 8 years operation of Retrofitted Electric Coaster 
New Approaches in Engineering Research Vol. 13 Techno-Economic Analysis of Retrofitted Electric Coaster Introduction in University Campus

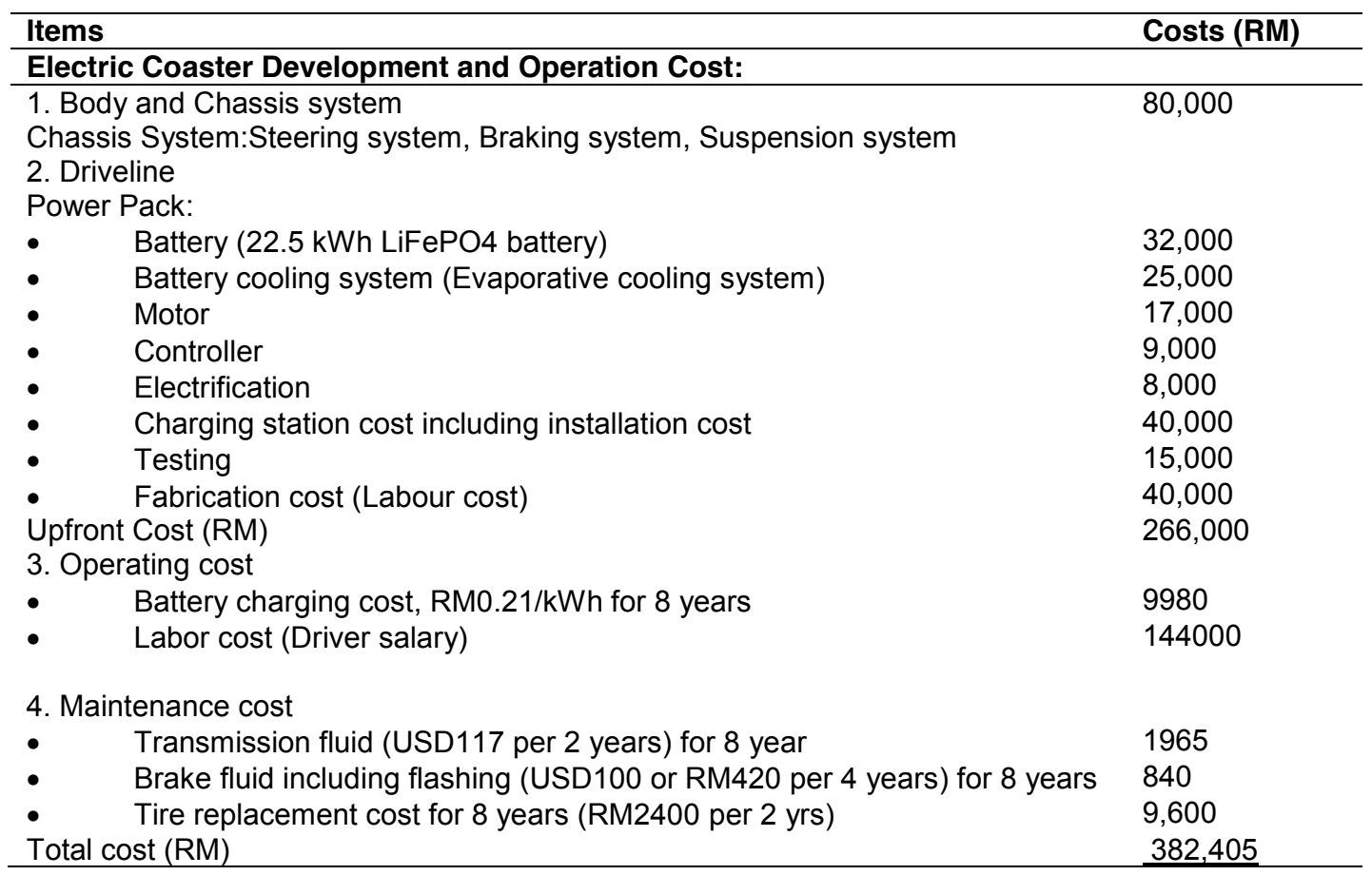

This conncept is the basis for the NPV (t) rule "if-means-Then" which indicates that the only investment should be made if the NPV(t) is positive,. It can be presented based on the Table 5. Based on the rule "If-means-Then", this project of REC introduction into the campus is highly acceptable as the NPV is found RM192339.57.

Table 5. Organization investment decision making rule "If-means-Then"

\begin{tabular}{lll}
\hline If & It means & Then \\
\hline NPV $>0$ & $\begin{array}{l}\text { The Electric Coaster } \\
\text { should be introduced } \\
\text { into the campus as } \\
\text { shuttle bus } \\
\text { The investment of } \\
\text { Electric Coaster project } \\
\text { should be continued }\end{array}$ & The Electric Coaster project may be accepted \\
NPV $<00$ & $\begin{array}{l}\text { The Electric Coaster } \\
\text { introduce would neither } \\
\text { gain or loss value for the } \\
\text { organization }\end{array}$ & $\begin{array}{l}\text { It should be indifferent in the decision whether to accept or } \\
\text { reject the Electric Coaster project. However, the } \\
\text { introduction of Electric Coaster should be continued as a } \\
\text { shuttle bus for the campus based on the environmental } \\
\text { impact and SDG goal achievement. }\end{array}$ \\
\hline
\end{tabular}

The benefit cost ratio can be estimated as,

$$
\frac{B}{C}=\sum_{t=0}^{N} \frac{B_{N}}{(1+r)^{N}} / \sum_{t=0}^{N} \frac{C_{N}}{(1+r)^{N}}
$$

The benefit and cost ratio has been presented in Table 6 .

Table 6. Benefit and cost ration 
New Approaches in Engineering Research Vol. 13 Techno-Economic Analysis of Retrofitted Electric Coaster Introduction in University Campus

\begin{tabular}{llll}
\hline Year & $\mathbf{( 1 + r}^{\mathbf{t}}$ & Cost & Benefit \\
\hline 1 & 1.03 & 258252.43 & 284854.37 \\
2 & 1.06 & 250730.51 & 276557.64 \\
3 & 1.09 & 243427.68 & 268502.56 \\
4 & 1.13 & 236337.55 & 260682.10 \\
5 & 1.16 & 229453.94 & 253089.42 \\
6 & 1.19 & 222770.81 & 245717.88 \\
7 & 1.23 & 216282.34 & 238561.15 \\
8 & 1.27 & 209982.85 & 231612.67 \\
& & $\sum_{t=0}^{N} \frac{C_{N}}{(1+r)^{N}}$ & $\sum_{t=0}^{N} \frac{B_{N}}{(1+r)^{N}}$ \\
Benefit $/$ Cost, & & $=1867238.12$ & \\
$\sum_{t=0}^{N} \frac{B_{N}}{(1+r)^{N}}$ & $\sum_{t=0}^{N}(1+r)^{N}$ & $\frac{2059577.69}{1867238.12}=1.103$ & \\
\hline
\end{tabular}

The estimated new present values of electric coaster has been presented in Table 7.

Table 7. Net present value of the electric coaster after 8 year operation

\begin{tabular}{|c|c|c|c|c|c|}
\hline $\begin{array}{l}\text { Benefit (B), } \\
\text { RM }\end{array}$ & $\begin{array}{l}\text { Total cost(C), } \\
\text { RM }\end{array}$ & $\begin{array}{l}\text { Net Benefit } \\
\text { (B-C), RM }\end{array}$ & $\begin{array}{l}\text { Discount } \\
\text { rate }(r), \%\end{array}$ & Year & $\begin{array}{l}{ }^{\star} N P V(t) \\
=(B-C) /(1+r)^{t}, R M\end{array}$ \\
\hline 293,000 & 266,000 & 27,000 & 3 & 1 & 26601.94 \\
\hline 293,000 & 266,000 & 27,000 & 3 & 2 & 25827.13 \\
\hline 293,000 & 266,000 & 27,000 & 3 & 3 & 25074.88 \\
\hline 293,000 & 266,000 & 27,000 & 3 & 4 & 24344.55 \\
\hline 293,000 & 266,000 & 27,000 & 3 & 5 & 23635.48 \\
\hline 293,000 & 266,000 & 27,000 & 3 & 6 & 22947.07 \\
\hline 293,000 & 266,000 & 27,000 & 3 & 7 & 22278.71 \\
\hline 293,000 & 266,000 & 27,000 & 3 & 8 & 21629.81 \\
\hline \multicolumn{5}{|c|}{ Net present value after 8 years operation (RM) } & 192339.57 \\
\hline
\end{tabular}

$N P V(t)=$ Net present value $(N P V(t))$ for time.

\subsection{Electric Coaster Benefit Analysis}

Basically, these 280 students will use the EC coaster facilities around the campus without using their won transport. These 280 students will be benefited for not using their own transport and they are able to save money,

$$
S T B_{p d}=\frac{C D}{T D_{p L}} * P D_{p L} * N
$$

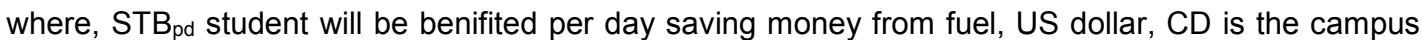
distance in $\mathrm{km}, T D_{\mathrm{pL}}$ is the distance travel by the student own transport per litre of gasolene, $\mathrm{km} / \mathrm{litre}$ and $P D_{p L}$ is the price of gasolene per litre, $R M$ and $N$ is the number of students. If the campus distance (CD) is considered $2.5 \mathrm{~km}, T D_{p L}$ is $0.17 \mathrm{~L}$, and $P D_{p L}$ is $R M 2.5$, the computed STBpd will be RM297.5 student. However, one student will be able to save for a year RM271.9 and 280 students will be able to save RM78,408. 


\subsection{EC Advantages in the Campus over the DEPC}

The advantages of retrofitted electric coaster (EC) over the diesel engine power coaster (DEPC) has been made based on the operating cost, maintenenace cost, low carbon campus, carbon trading (CT) and health impact. The annual net benefit due to the operation of the electric coaster (EC) in the campus instead of diesel enegine powered coaster (DEPC), Most interestingly, the students WTP survey result shows that the students are willingness to pay as RM5.00 per student per month. They have reported it is part of their money that they spend in their own transport. However, they have reported that the waiting time at parking point could be delay. The sample of the survey questionnaire has been shown in Table 8.

The pilot survey has been conducted with 200 students by using survey questionnaire as shown in Table 8 . It is quantified that $60 \%$ of students are willingness to pay RM5.00, $40 \%$ are willingness to pay RM10 per month which they considered as the part of their own transportation cost. It is noted that the most of the students use motor bike as their personal transport to enter and leave of their respective kulliyyah by travelling $2.5 \mathrm{~km}$. The fuel (gasolene) consumption of motor bike in a single round of the campus is 0.17 litre which price is $\mathrm{RM0} 0.5$ per day.

i. Without considering WTP and carbon trading

$$
A N B_{t}=\frac{\operatorname{Cos} t(t)^{I C E C}-\operatorname{Cos} t(t)^{E C}}{(1+r)^{t}}
$$

ii. With considering WTPs and CT

$$
A N B_{t}=\frac{\operatorname{Cost}_{t}^{I C E C}-\operatorname{Cost}_{t}^{E C}}{(1+r)^{t}}+C T_{t}+W_{t}[n=280]
$$

where, CT is the carbon trading which is considered as USD50/tonne and WPs is the students willingless to pay and $n$ is the number of students, and $r$ is the rate of inflation in percentage. The avearage rate of inflation is considered as $2.2 \%$. In this study we have identified that 280 students would like to pay RM5.00 (USD 1.2) per months for the low carbon campus.

$$
\begin{aligned}
N P V(t)= & \left(\operatorname{Cost}_{t=0}^{I C E C}-\operatorname{Cost}_{t=0}^{E C}\right)+\frac{\left(\operatorname{Cost}_{t}^{I C E C}-\operatorname{Cost}_{t}^{E X}\right)}{(1+r)^{t}} \\
& +\frac{\left(\operatorname{Cos}_{t=2}^{I C E C}-\operatorname{Cost}_{t=2}^{E C}\right)}{(1+r)^{t=2}}+\ldots \ldots \ldots+\frac{\left(\operatorname{Cost}_{t=8}^{I C E C}-\operatorname{Cost}^{E C}\right)}{(1+r)^{t=8}}
\end{aligned}
$$

\subsection{Retrofitted Electric Coaster Fabrication cost and Evaluation}

\subsubsection{Investment costs}

The costs of the investment consist of three parts, body and chassis, the battery and the motor as shown in Table 9. The body and chassis system includes steering and braking system, suspension system. The power pack involves with battery cost and battery cooling costs. The motor of the electric car needs to be developed by controller, electrification and charging station. 
New Approaches in Engineering Research Vol. 13 Techno-Economic Analysis of Retrofitted Electric Coaster Introduction in University Campus

Table 8. Pilot survey questionnaire for the student's willingness to pay

No. Descrition of Questionnaire [Please circle your answer]

1. What kind of transportaion you are using inside the campus?

a. Private car

b. Public transport

2. If you don't use public transportation, what are the reasons?

a. Public transportation is not regular

b. Public transportation is not frequent

c. I have to wait for long time

d. Public transportation is crowded

3. How much do you spend every month for your transportation around the campus traveling?

a. RM 200

b. RM 150

c. RM 100

d. RM 50

e. Others, please specify

3. Do you know about air pollution index?

a. Yes

b. No

4. If you know about air pollition index, what is the source of your knowedge?

a. Newspaper

b. Television

c. Internet

d. Others, please specify.

5. Did you experience any of these health problems during the last three months?

a. Eye irritation

b. Sneezing

c. Ashthma

d. Coughing

6. Which mode of transport would you prefer for the low-carbon IIUM campus?

a. Internal Combustion Engine Transport

b. Electric Transport

7. If the campus will arrange electric-bus transportation for students to enter and leave the respective kulliyyah to reduce $\mathrm{CO}_{2}$ emissions, improve air pollution and health problems, how much are you willing to pay for electric-bus service per month?

a. RM5

b. RM10

c. RM15

d. Not interested

The benefit of REC introduction in the campus provides the benefits in tremendous ways: less $\mathrm{CO} 2$ emission by replacing the 480 motor bikes which can polluted the environment with $\mathrm{CO} 2$ emission about 1.33 metric ton to run the $2.4 \mathrm{~km}$ around the campus, money saving about USD14800 annually, sustainable environment as shown in Table 10.

\subsubsection{Operation costs}

The "fuel" in the electric vehicle is electricity, and the operation costs are thereby mainly based on the cost of electricity. The electric engine works in the manner that electricity from the battery is converted into a rotating movement of the engine shaft. This movement is transferred to the wheels, which make the vehicle drive. The operation of the car involves electrification costs, testing cost, battery charging costs and tire replacement costs. Here it is assumed that the life of the battery is 8 years. It is also assumed that the tire is replaced every 3 years. The costs of the development of the electric vehicle is calculated and is shown in Table 11. It is observed that the total costs of development of electric coaster is RM190,000 (USD45,200). 
New Approaches in Engineering Research Vol. 13 Techno-Economic Analysis of Retrofitted Electric Coaster Introduction in University Campus

Table 9. Cost of the Retrofitted Electric Coaster fabrication

\begin{tabular}{ll}
\hline \multicolumn{2}{l}{ Electric Coaster (EC): } \\
\hline 1. Body and Chassis system & \\
Chassis System:Steering system, Braking system, Suspension system \\
2. Driveline \\
- Battery pack (22.5 kWh LiFePO4 battery) \\
- $\quad$ Battery cooling system (Evaporative cooling system) \\
- $\quad$ Motor & 32,000 \\
- $\quad$ Controller & 25,000 \\
- $\quad$ Electrification & 17,000 \\
- $\quad$ Charging station cost including installation cost & 9,000 \\
3. Fabrication cost & 8,000 \\
4. Testing cost & 40,000 \\
Total (RM) & 40,000 \\
\hline
\end{tabular}

Table 10. Benefit of Electric Coaster Introduction in the University campus

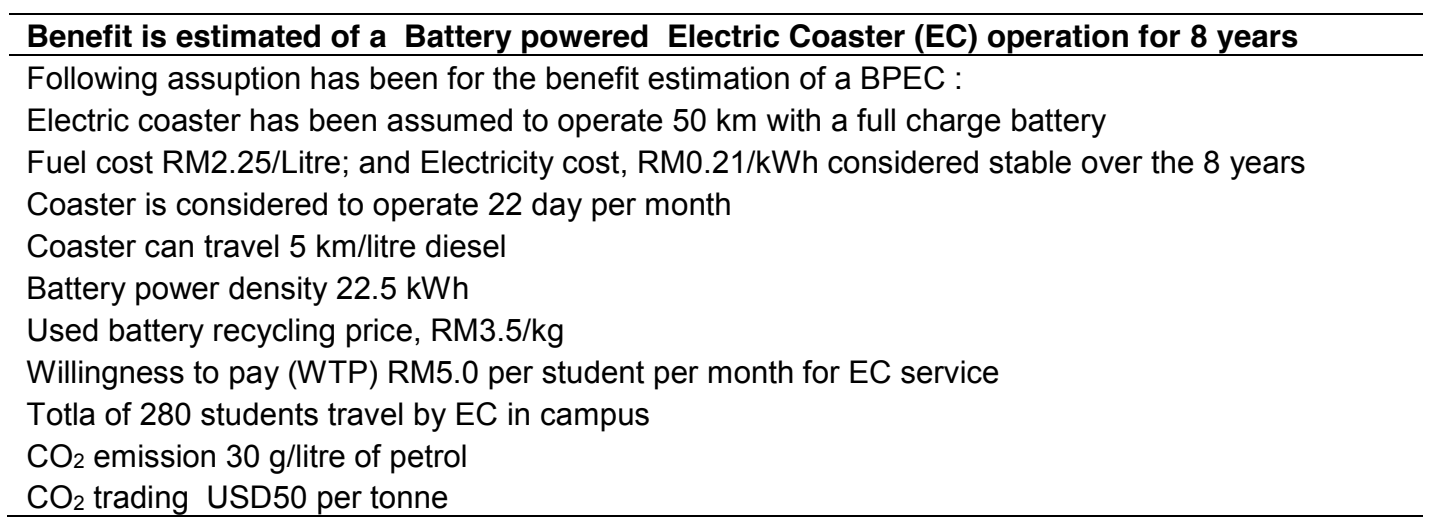

\begin{tabular}{|c|c|c|c|}
\hline \multirow[t]{2}{*}{ Description } & \multicolumn{3}{|c|}{ Benifites of Electric Coaster Introduction for 8 years operation } \\
\hline & Coaster'CE & CoasterElectric & Benefits (RM) \\
\hline${ }^{*}$ Energy Cost, RM & $\begin{array}{l}66,200 \\
\text { [Diesel needs 21,128 L] }\end{array}$ & $\begin{array}{l}9,979 \\
\text { [Electricity for battery charging, } \\
47520 \mathrm{kWh} \text { ] }\end{array}$ & 56221 \\
\hline $\begin{array}{l}\text { Maintenance cost, } \\
\text { RM }\end{array}$ & 29,600 & 7,605 & 22,092 \\
\hline Investment cost, RM & 462,000 & 286,000 & 176,000 \\
\hline $\mathrm{CO}_{2}$ trading, $\mathrm{RM}$ & - & $\begin{array}{l}2200 \\
{\left[\mathrm{CO}_{2} \text { emission saving }=10.5 \mathrm{MT}\right\}}\end{array}$ & 2,200 \\
\hline Reselling price, $\mathrm{RM}$ & 80,000 & 40,000 & -40000 \\
\hline WTP & - & 134,400 & 134,400 \\
\hline Registration & 1000 & 1000 & 0.00 \\
\hline Driver salary & 144000 & 144000 & 0.00 \\
\hline \multicolumn{3}{|c|}{ Annual Net Benefits (RM) } & 350,913 \\
\hline
\end{tabular}


New Approaches in Engineering Research Vol. 13 Techno-Economic Analysis of Retrofitted Electric Coaster Introduction in University Campus

Table 11. Benefits of EC Operation for 8 years

\begin{tabular}{|c|c|}
\hline Items/Description & Benefits (RM) \\
\hline $\begin{array}{l}\text { (i) Saving from Fuel =(fuel cost-electricity consumption cost=RM5,040 /year) for } 8 \\
\text { years }\end{array}$ & 56,221 \\
\hline Fuel (diesel) cost=RM66200 @5\% increment & \\
\hline Electricity (for battery charging) cost $=\mathrm{RM} 0.21^{*} 22.5^{\star} 22^{*} 12^{\star} 8=\mathrm{RM} 9980$ & \\
\hline $\begin{array}{l}\text { Saving from maintenance cost for } 8 \text { years } \\
\mathrm{CO}_{2} \text { emission saving }=10.5 \text { Metric Tonne }\end{array}$ & 30,627 \\
\hline${ }^{*} \mathrm{CO} 2$ trading for 10.5 metric tonne/per year (RM170/tonne ${ }^{*} 10.5$ tonne ${ }^{\star} 8$ years) & 14,280 \\
\hline${ }^{* *}$ Traffic noise costs average $\$ 0.079 / \mathrm{km}$ for 8 years $\left(45^{*} 30^{*} 12 * 8 * \$ 0.079 * 4.2=\right)$ & 5,375 \\
\hline Reselling price of electric coaster at the end of 8 years & 40,000 \\
\hline${ }^{* * *}$ Health benefit from a student for 8 years $\left(\mathrm{RM}^{*} 12^{*} 8 * 500\right)$ & 30,000 \\
\hline $\begin{array}{l}* * \star \star \text { Income from students (RM5.00 per month per student }{ }^{*} 280 \text { students for a } \\
\text { month }^{\star} 8 \text { month per year } 8 \text { years }\end{array}$ & 134,400 \\
\hline $\begin{array}{l}300 \mathrm{~kg} \text { Used battery selling for recycling, (RM3.5/kg*300kg=RM1834 } \\
\text { Total benefit (RM) }\end{array}$ & $\begin{array}{l}1,834 \\
\mathbf{3 1 2}, 737 \\
\end{array}$ \\
\hline
\end{tabular}

Table 12. Maintenance Cost for 8 years

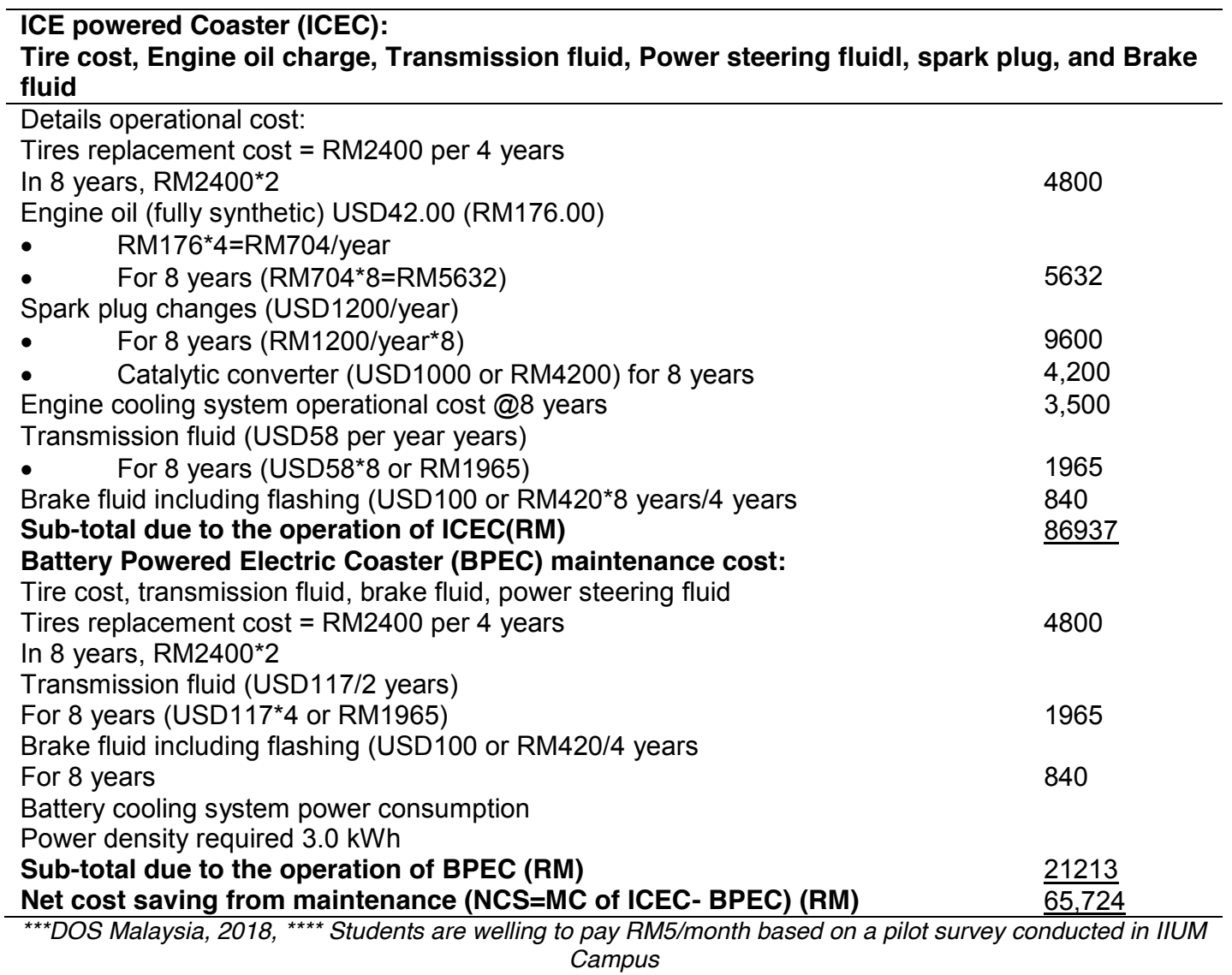

\subsubsection{Maintenance cost}

The maintenece cost of the REC has been estimated for 8 years which is very about Ringgit Malaysia (RM) 65700 less than the ICE power coaster. The maintenance cost of REC has shwon in Table 12. 


\subsection{Cost Analysis and Interpretation}

(i) The cost of the electric coaster has been made with considering the stable price of fuel and electricity over the 8 years life.

(ii) The cost of the electric coaster has been made with considering the rate of inflation, $r=3 \%$

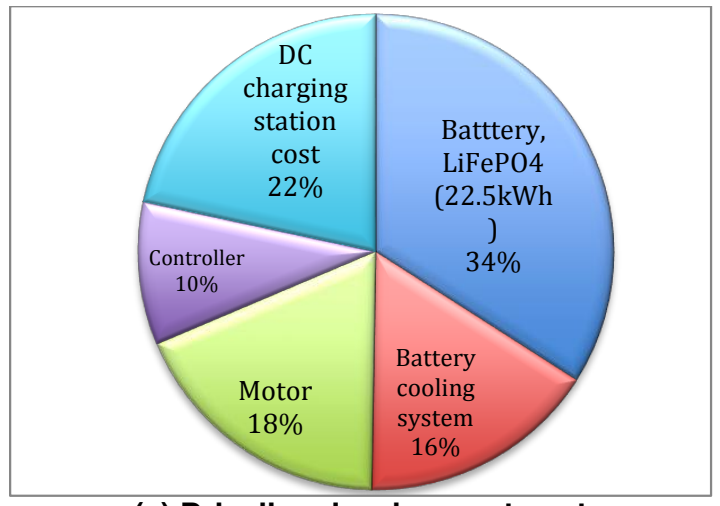

(a) Driveline development cost

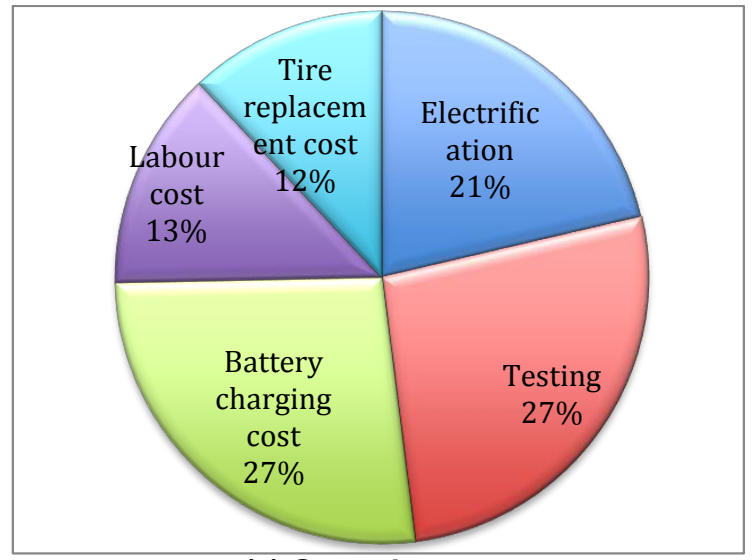

(c) Operating cost

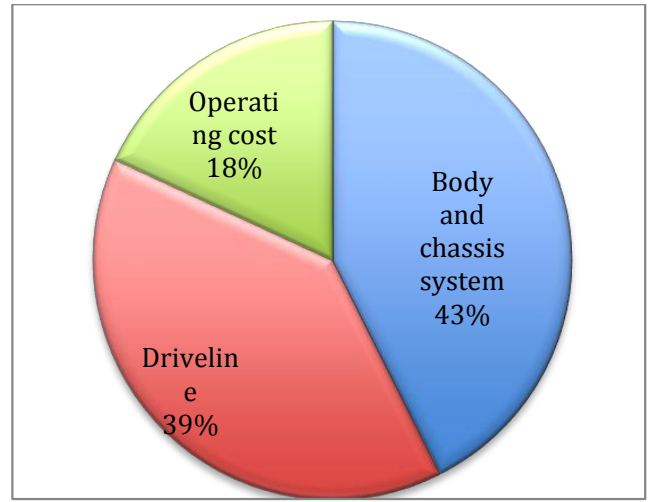

(b) Electric coaster development cost

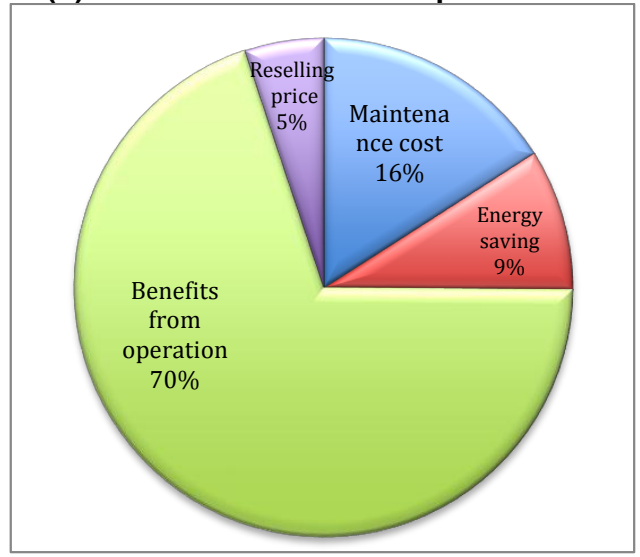

(d) Benefits

Fig. 2. Breakdown cost of REC

Figs. 3-4 shows that the energy cost of REC is $16 \%$ lower than the energy cost of diesel enegine powered electric coaster. In addition, the maintenance cost of REC is $70 \%$ lower than the DEPC. It could be concluded that the saving money of REC from operation about RM82000 in every 5 years operation. However, reselling price of the DEPC is 40000 more than the REC as the electric coaster will be very old after 10 years. None of the system especially chassis will be not effective. It would be sell as scrap materials. Furthermore, the carbing and old battery trading may add some value to the total saving of cost of REC operation. Thus it could be concluded that the electric coaster is a sustainable fleet-in-operation of the university campus which is good for the enhance the sustanable index of the campus, which can be justifed from the analysis presented in Table 13. 
New Approaches in Engineering Research Vol. 13 Techno-Economic Analysis of Retrofitted Electric Coaster Introduction in University Campus

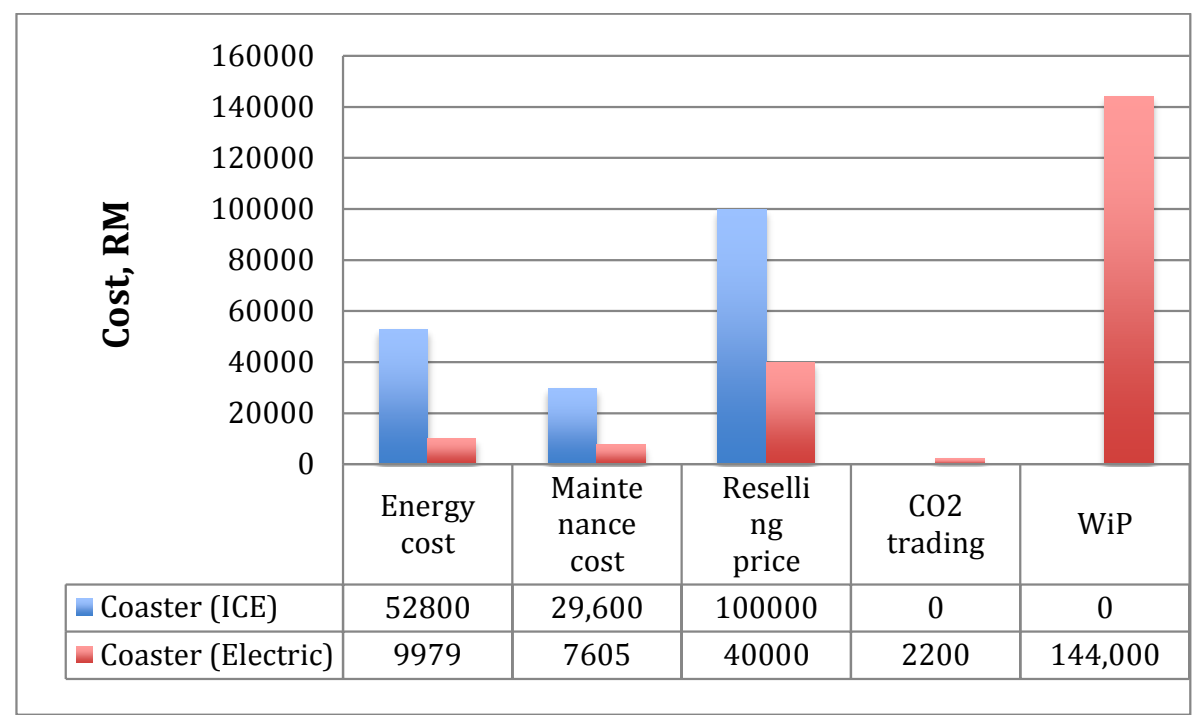

Fig. 3. Cost comparism between internal combustion engine coaster and electric coaster

Table 13. Cost comparison between the diesel engine power coaster and retrofitted electric coaster

\begin{tabular}{|c|c|c|c|c|c|c|c|c|}
\hline \multicolumn{9}{|c|}{ Diesel Engine Power Coaster } \\
\hline $\begin{array}{l}\text { Description of } \\
\text { Cost }\end{array}$ & $\begin{array}{l}\text { Cost, RM } \\
\text { Year }\end{array}$ & & & & & & & \\
\hline & 1 & 2 & 3 & 4 & 5 & 6 & 7 & 8 \\
\hline Upfront cost & 462000 & & & & & & & \\
\hline Energy cost & 6933 & 7279 & 7643 & 7575 & 8037 & 8278 & 8526 & 8782 \\
\hline Maintenance cost & 10750 & 11857 & 11747 & 12099 & 12462 & 12836 & 13221 & 13618 \\
\hline Registration & 2500 & 2500 & 2500 & 2500 & 2500 & 2500 & 2500 & 2500 \\
\hline Insurance & 2000 & 2000 & 2000 & 2000 & 2000 & 2000 & 2000 & 2000 \\
\hline $\begin{array}{l}{ }^{1} \text { Total DEPC Cost } \\
\text { (RM) }\end{array}$ & 484183 & 23637 & 23890 & 24175 & 24999 & 25614 & 24247 & 26900 \\
\hline \multicolumn{9}{|c|}{ Retrofitted Electric Coaster } \\
\hline Upfront & 286000 & & & & & & & \\
\hline Energy cost & 1247 & 1247 & 1247 & 1247 & 1247 & 1247 & 1247 & 1247 \\
\hline Maintenance cost & 7605 & 8068 & 8310 & 8559 & 8816 & 9081 & 9081 & 9634 \\
\hline Registration & 2500 & 2500 & 2500 & 2500 & 2500 & 2500 & 2500 & 2500 \\
\hline Insurance & 1500 & 1500 & 1500 & 1500 & 1500 & 1500 & 1500 & 1500 \\
\hline $\begin{array}{l}\text { 2Total REC Cost } \\
\text { (RM) }\end{array}$ & 298852 & 13315 & 13557 & 12306 & 14063 & 14328 & 14328 & 14881 \\
\hline
\end{tabular}

Cost Saving (CS) of Retrofitted Electric Coaster over the Diesel Engine Powered Coaster has been made using the equation:

\begin{tabular}{|c|c|c|c|c|c|c|c|c|}
\hline \multicolumn{9}{|c|}{$\underline{\left(\operatorname{Cost}_{t}^{D E P C} \operatorname{Cost}_{t}^{E \oint}\right)}$} \\
\hline $\begin{array}{l}{ }^{3} \text { Annua } \\
\text { I CS }\end{array}$ & 179933 & 9729 & 9456 & 10545 & 9433 & 9452 & 8066 & 9488 \\
\hline${ }^{4} \mathrm{CCS}$ & 189756 & 199485 & 208941 & 219486 & 228919 & 238371 & 246436 & 255924 \\
\hline
\end{tabular}


New Approaches in Engineering Research Vol. 13 Techno-Economic Analysis of Retrofitted Electric Coaster Introduction in University Campus

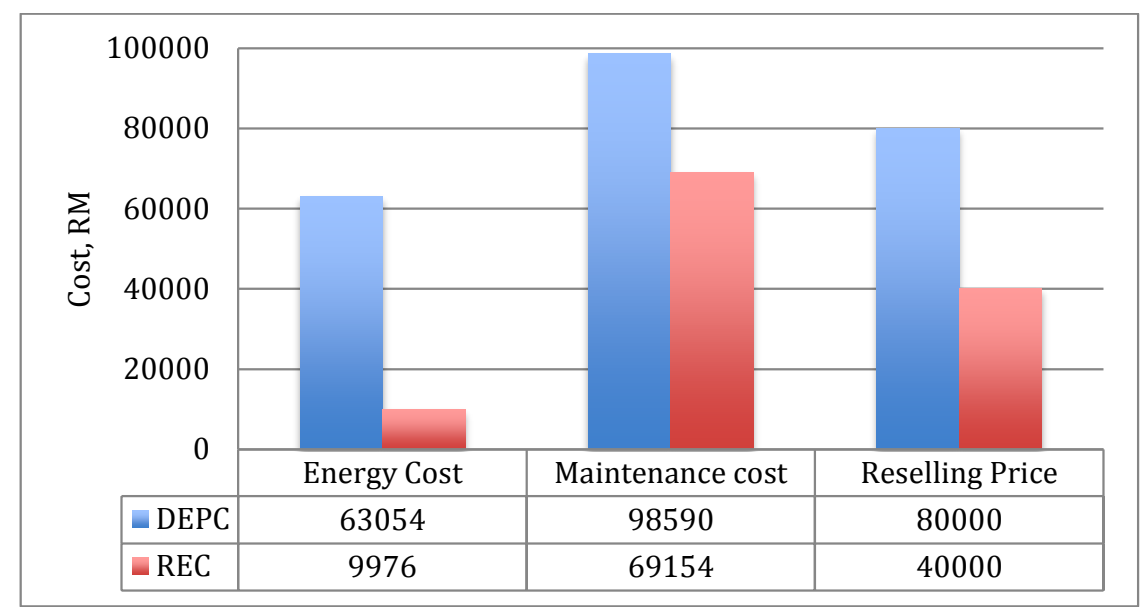

Fig. 4. Comparison between the cost of diesel engine power coaster and electric coaster

\section{CONCLUSION}

Electric coasters that have been renovated are more environmentally friendly than coasters that are powered by diesel, according to research. The cost of operating a campus as a shuttle bus is justified by retrofitted electric coaster operation expenses, energy costs, $\mathrm{CO} 2$ reduction, and maintenance costs. The university may be able to retrofit the old ICE-powered campus shuttle bus rather than scrapping it.

\section{ACKNOWLEDGEMENT}

The authors are grateful to the Research Management Centre (RMC), International Islamic University for financing the Flagship Rig Project (Ref. IRF19-032-0032) and Research Initiative Grant Scheme (publication) (Ref: PRIGS18-006-0006).

\section{COMPETING INTERESTS}

Authors have declared that no competing interests exist.

\section{REFERENCES}

1. Jeevak SL, Daigavhane PM, Mithu S (2020) A Critical Approach Towards a Smarter Battery Management System for Electric Vehicle. June 2020, $4^{\text {th }}$ International Conference on Trends in Electronics and Informatics.

2. McKerracher C; 2017.

Available: https://about.bnef.com/blog/electric-vehicles-to-be-35-of-global-new-car-sales-by2040/\# ftnref

3. Kim MY, $\mathrm{Kim} \mathrm{CH}$, Kim JH, Moon GW. A chain structure of switched capacitor for improved cell balancing speed of lithium-ion batteries', IEEE Transactions on Industrial Electronics. (PDF) Power optimisation of electric coaster. 2014;61(8):3989-3999.

Available:https://www.researchgate.net/publication/326003651_Power_optimisation_of_electric coaster [accessed Feb 21 2021].

4. Gering KL, Sazhin SV, Jamison DK, Michelbacher CJ, Liaw BY, Dubarry M, Cugnet M. 'Investigation of path dependence in commercial lithium-ion cells chosen for plug-in hybrid vehicle duty cycle protocols', Journal of Power Sources. 2011;196(7):3395-3403.

5. Guo X, Kang L, Huang Z, Yao Y, Yang H. Research on a novel power inductor-based bidirectional lossless equalization circuit for series-connected battery packs', Energies, (PDF) Power optimisation of electric coaster. 2015;8(6):5555-5576. 
Available:https://www.researchgate.net/publication/326003651_Power_optimisation_of_electric coaster [accessed Feb 21 2021].

6. $\quad$ Rahman Ataur, Rahman Mizanur., Sany Ihsan Izan, Ahmad Faris Ismail. Power optimization of Electric Coaster. International Journal of Electric and Hybrid Vehicles, Inderscience Publisher. 2018;10(2):272-278.

7. Korejwa E. The Returns to Vehicle Electrification: An Assessment of the Economic and Budgetary Impacts of Electric Vehicle Adoption in Oregon, Drive Oregon; 2015.

8. Rahman A, Afroz R, Alam Z. (2014) 'Development of electric vehicle: public perception and attitude, the Malaysian approach', World Review of Intermodal Transportation Research. 2014;5(2):149-167.

9. Ataur R, Azri M, Kyaw MA, Ahmad FI, Mohiuddin AKM, Sany II. Prospect and challenges of electric vehicle adaptability: An energy review Malaysia. Energy Education Science and Technology Part A: Energy Science and Research. 2018;36(3):139-151.

10. Stephen Hall, Simon Peter Shephard, Zia Wadud. The Innovation Interface: Business model innovation for electric vehicle futures. University of Leed; 2017.

11. Geert Verbong, Frank W. Geels. The Ongoing Energy Transition: Lessons from a SocioTechnical, Multi-Level Analysis of the Dutch Electricity System (1960-2004). Energy Policy, February; 2007.

12. Woolf T, Willian S, Erin M, Kenji T. Energy Efficiency Cost-Effectiveness Screening. Synapse Energy Economics, Inc; 2012.

13. Ongel A, Loewer E, Roemer F, Sethuraman G, Chang F, Lienkamp M. Economic assessment of autonomous electric microtransit vehicles. Sustainability. 2019;11(3):648.

14. Christian Lerch, Fabian Kley, David Dallinger. New business models for electric cars: A hollinstic approach. Energy Policy; 2010.

15. Ahmed Yousuf Saber, Ganesh K Venayangamoorthy. Plug-in-vehicles and renewable energy source for cost and emission reduction. IEEE Transactions on Industrail Electronics; 2011.

(c) Copyright (2021): Author(s). The licensee is the publisher (B P International). 